\title{
The South Kalimantan Ulama's Leadership in Covid-19 Pandemic Era
}

\author{
M. Kholis Amrullah \\ IAIN Metro Lampung \\ Email: Kholisamrullah90@gmail.com
}

\begin{abstract}
Ulama are community leaders who have the highest religious competence in society and deliver scholars to become religious leaders. Apart from religious leadership, ulama also have social leadership that is able to control many individuals or groups. This study aims to reveal the form of ulama leadership in South Kalimantan during the Covid-19 conditions. This study uses a qualitative approach with descriptive analysis. The data is taken from some information posted on trusted websites. The results showed that ulama in South Kalimantan practiced transformational religious leadership in society. Ulama in the context of this research are ulama in South Kalimantan who often get the spotlight from the public. With the interaction of scholars on leadership, the leadership is modeled on religious leadership. Religious leadership offers religious, theological, moral, ethical, and spiritual guidance on most aspects of the daily life of Muslims.
\end{abstract}

Keywords: leadership, ulama, the covid-19 pandemic.

\begin{abstract}
Abstrak: Ulama merupakan tokoh masyarakat yang memiliki kompetensi beragama tertinggi di dalam masyarakat dan menghantarkan ulama menjadi pemimpin agama. Selain kepemimpinan beragama, ulama juga memiliki kepemimpinan sosial yang mampu mengendalikan banyak individu atau kelompok. Penelitian ini bertujuan untuk mengungkap bentuk kepemimpinan ulama di Kalimantan Selatan selama kondisi covid-19. Penelitian ini menggunakan pendekatan kualitatif dengan analisis deskriptif. Data penelitian diambil dari beberapa informasi yang dimuat di situs web terpercaya. Hasil penelitian menunjukkan bahwa ulama di Kalimantan Selatan mempraktikkan kepemimpinan transformational beragama dalam masyarakat. Ulama dalam konteks penelitian ini adalah ulama di Kalimantan Selatan yang sering mendapat sorotan dari public. Dengan adanya keterlibatan ulama pada kepemimpinan, maka kepemimpinannya bermodel kepemimpinan religius. Kepemimpinan religius menawarkan bimbingan religius, teologis, moral, etis, dan spiritual pada sebagian besar aspek kehidupan sehari-hari umat Islam.
\end{abstract}

Kata-kata kunci: kepemimpinan, ulama, pandemi covid-19.

\section{Introduction}

Islamic religious leaders in Indonesia have several written titles attached to a name. The written titles have different designations based on their respective 
regions, such as Buya ${ }^{1}$ for West Sumatra, Tuan Guru for Lombok ${ }^{2}$ and Bima ${ }^{3}$, and Kyai for Kalimantan ${ }^{4}$ and Java ${ }^{5}$ as well as several titles in other regions of the archipelago. In this study, as a synonym to mention the terms of Islamic religious leaders, the researcher uses the term Ulama ${ }^{6}$ as a substitute to refer to Islamic religious leaders. Several studies on ulama and their role in all areas of life in the archipelago have been suggested by previous researchers. The role of Ulama as inheritors of the Prophets is their role in general in the context of the religious life of Indonesian society. Ulama convey messages contained in the holy book of Al-Qur'an and the Hadith of the Prophet ${ }^{7}$. Through the delivery of the contents of this holy book, Ulama are seen as able to solve problems of customs or habits that become disputes in community. ${ }^{8}$ The Ulama can also become a regional or institutional leader or be involved in State politics. ${ }^{9}$

During the Covid-19 pandemic, there were many conflicts between the government and the people. The most common contradictions are in matters of religious worship. Such as carrying out compulsory prayers, ${ }^{10}$ Islamic boarding school education, ${ }^{11}$ and dismissing the religious gathering. ${ }^{12}$.Indeed, from a social construction perspective, an Ulama does not have any position in the government bureaucracy, but their existence becomes a direction for the community, especially the congregation or the followers.

1 Jannatul Husna bin Ali Nuar, Minangkabau Clergies and The Writing of Hadith, Ushuluddin, Vol. 24, no. 1, 2016.

2 Aswasulasikin, Siti Irene Astuti Dwiningrum, Sumarno, Tuan Guru sebagai Tokoh Pembangunan Pendidikan di Pedesaan, Pembangunan Pendidikan: Fondasi dan Aplikasi, Vol. 3, No. 1, 2015.

3 Ruslan, Luthfiyah, Pendampingan Ustadz dan Tuan Guru Pesantren melalui Pneguatan Nilai-nilai Multikultural untuk Mencegah Radikalisme Islam Berbasis Pesantren di Kota Bima, Engagement, Vol. 4, No. 1, 2020.

${ }^{4}$ Muhamad Ratodi, Arfiani Syariah, Perubahan Spasial Wilayah Permukiman Muslim Sekumpul Terkait Aktivitas Dakwah KH Muhammad Zaini Abdul Ghani, Emara: Indonesian Journal of Architecture, Vol. 5, No. 2, 2019.

${ }^{5}$ Ujang Khiyarusoleh, Konseling Indigenous Pesantren (Gaya Kepimpinan Kyai dalam Mendidik Santri), Jurnal Kependidikan, Vol. 6, No. 3, 2020.

${ }^{6}$ Ahmad Adi Suradi, Buyung Surahman, Kiai's Role as Ulama and Umara: Implications to The Pesantren Education, Masyarakat, Kebudayaan, dan Politik, Vol. 33, No. 2, 2020.

7 Edi Bahtiar, Aktualisasi Peran Ulama Sebagai Warasatul Anbiya dalam Konteks Kehidupan Beragama dan Bernegara, Riwayah, Vol. 4, No. 1, 2018

8 Akhmad Haries, Hervina, Pandangan Ulama tentang Hukum Surung Sintak pada Pelaksanaan Zakat Fitrah di Kota Samarinda, Fenomena, Vol. 5, No. 2, 2013.

${ }^{9}$ Arifin Suryo Nugroho, Visi Politik Seorang Ulama, Khazanah Pendidikan, Vol. 13, No. $2,2020$.

10 https://kalsel.antaranews.com/berita/159054/guru-kapuh-ijtihad-ulamakewajiban-shalat-jumat-gugur-karena-cegah-wabah-corona, diunduh kamis 19 November 2020.

11 https://kalsel.antaranews.com/berita/154558/video-cegah-corona-guru-kapuhliburkan-ponpes, downloaded on Thursday 19 November 2020.

12 https://kanalkalimantan.com/antisipasi-corona-guru-zuhdi-liburkan-semuapengajian-berikut-jadwal-rutinnya/, downloaded on Thursday 19 November 2020. 
Ulama in the context of this research are ulama in South Kalimantan who often get the spotlight from the public. With the involvement of the ulama in leadership, the leadership model becomes religious leadership. This religious leadership offers religious, theological, moral, ethical, and spiritual guidance on most aspects of the daily life of Muslims ${ }^{13}$. Based on the offer of guidance, it can be seen that the ulama are filling the "void" in the realm of socio-religious relations. Religious guidance leads people to their peace in carrying out daily worship that involves themselves with God. The direction of the people on theological matters is to require people to remain and increase their belief in God without associating Him with other creatures. Theological study is the study of divinity, so that the focus of its improvement is on human faith.

Meanwhile, the relationship among human requires the existence of community rules that are formed by the community itself. These rules must also be agreed upon to avoid misunderstanding. The role of the ulama is to provide moral guidance to Muslims to be able to carry out the rules of society properly without causing conflicts. Furthermore, ethical guidance from Ulama is needed so that people are able to classify good and bad things. These good and bad conditions are sometimes subjective and sometimes objective. In order to determine this subjective and objective meaning, spiritual knowledge that is more applicable than ethical guidance is required.

Ulama are community leaders who have the highest religious competence or are considered the highest in society. So it was agreed that through a scholar, the community would be able to gain religious knowledge that was socially and unrelated. Apart from religious leadership, there is also social leadership which is able to control many individuals or groups. Social leadership competencies may be obtained or developed by doing skills; action; productive behavior, approaching challenges for self-development, and improving thinking skills. ${ }^{14}$

The entire world community, especially the Indonesian people, have realized that currently all areas of life are constrained by Covid-19. This phenomenon requires the government to make a policy. Sometimes not all of these policies can be followed by the community. Especially if it is related to the economy, it is said that the profit and loss factor is a determining factor for people's obedience to the government. This research will review the existence of ulama in South Kalimantan regarding this kind of social phenomenon. The focus of the problem is directed at the verbal and nonverbal actions of Ulama related to the implementation of health policies by the government during Covid-19 era. This study also analyzed the form of Ulama leadership in South Kalimantan through verbal and non-verbal actions.

13 Nezar Faris, Mohamad Abdalla, Leadership in Islam Thoughts, Processes and Solutions in Australian Organizations, Switzerland: Springer, 2018, p. 42.

${ }^{14}$ Frank Guglielmo, Sudhanshu Palsule, The Social Leader: Redefining Leadership for Complex Social Age, Brookline: Bibliomotion, 2014, p. 72. 
This research is a qualitative research that seeks to investigate social life naturally, such as examining or exploring what humans say, do, feel, and act $^{15}$. In this study, the activities raised by Ulama during the Covid-19 pandemic are phenomena that require theoretical analysis to make them a form of spiritual leadership. Researchers will explore several activities of ulama in Kalimantan for data collection through news circulating on the internet. Qualitative research refers to data that describe the quality of meaningful objects. ${ }^{16}$ In this study, information about the quality of an object was obtained from the main data source; several trusted news websites. The data collection technique used in this study was searching for related documents on websites on the internet related to activities or appeals or fatwas during the Covid-19 pandemic raised by ulama in South Kalimantan.

Qualitative data analysis is an overview of qualitative data relationships. ${ }^{17}$ The data analysis technique in this study uses three stages of analysis, namely describe, compare, relate ${ }^{18}$. Describe or describing is the activity of narrating the data that researchers get. In the narrative, the researcher does not add or subtract information. The researcher writes what is meant by the research data. Compare or comparing is the activity of comparing information in research data. Comparisons can be made by researchers in two ways; they are comparing the information in the research data and comparing the information in the research data with information outside the research data. Relate or linking is the activity of finding a relationship between information in research data and information in research data with information outside research data. The purpose of this association is to create a connection between information that may not be visible or unknown.

\section{The Ulama's Actions in Supporting the Government Programs}

The News of the first positive case of Covid-19 in South Kalimantan appeared on Sunday, March 22nd, 2020. Even though one day earlier the Governor of South Kalimantan had just raised the emergency response status for the Covid-19 pandemic ${ }^{19}$. In five months since the increase in Covid-19 status, the number of cases has increased to nine thousand cases. ${ }^{20}$ Following up on

15 Johnny Saldana, Matt Omasta, Qualitative Research: Analyzing Life, California: SAGE Publications, Inc, p. 2018

${ }^{16}$ Jeffrey Longhofer. Et. All., Qualitative Methods for Practice Research, Oxford: Oxford University Press, 2013, p. 38.

17 William Gibson, Andrew Brown, Working with Qualitative Data, California: SAGE Publications, Inc, 2009, p. 4.

$18 \mathrm{M}$, Kholis Amrullah, M. Irfan Islamy, Perencanaan Penelitian, Malang: Literasi Nusantara, 2020, p. 58.

19 https://kanalkalimantan.com/breaking-news-1-orang-positif-covid-19-di-kalselkasus-pertama-ditemukan/, downloaded on Sunday 22 November 2020.

20 https://kanalkalimantan.com/5-bulan-semenjak-kasus-pertama-covid-19-di-kalselnyaris-tembus-9-ribu-kasus/, downloaded on Sunday 22 November 2020 
the notification of the first case of Covid-19 from the Governor, KH. M. Ridwan Baseri or commonly known as Guru Kapuh who served as chairman of the Hulu Sungai Selatan Regency (HSS) Indonesian Ulama Council (MUI) directly appealed to the HSS community in particular to follow government recommendations in dealing with the Covid case ${ }^{21}$.

Guru Kapuh told the public that in facing this pandemic that is part of the health issue, then it is best to leave all decisions to their experts in the field of health, the medical team. He said, a similar incident also happened when he was visiting his teacher's house, KH. Zaini Abdul Ghani or commonly known as Guru Sekumpul. A male guest came in and told him that his wife was ill, and the doctor advised her to be hospitalized immediately. The group teacher advised the guest to follow what the doctor suggested, because the doctor is an expert in the field of health, so the wise way to solve the problem is to leave it to the expert.

Guru Kapuh supports government policies on reducing activities that have the potential to accumulate mass. This support is aimed at encouraging the public to anticipate the existence of the corona outbreak that has spread. ${ }^{22}$ The Kapun teacher explained that his support was also part of the follow-up to the MUI fatwa number 14 of 2020 concerning the Implementation of Worship in a Situation of the Covid-19 Outbreak which was set on March 16 th $2020 . .^{23}$ This fatwa recommends that the government implement super strict restrictions in responding to exit- the entry of goods and people in Indonesia, Muslims are obliged to obey and support government policy programs in dealing with Covid-19, and the public is expected to be able to be proportional to people diagnosed with covid-19.

On March 24, 2020, Guru Kapuh issued an appeal related to Islamic education throughout HSS 24 . The appeal stated that all Islamic boarding schools in HSS District were temporarily closed, all Al-Qur'an Education Parks were temporarily closed, and routine recitation was carried out using the online method. Not only that, he also appealed to all committees or managers of tabligh akbar activities, dhizikr assemblies, and other religious events held at mosques or other places to be closed. This appeal was conveyed as a form of his support for local government policies.

Guru Kapuh stipulated the law of fardhu 'ain (obligatory) from Friday praying and the obligation to pray in congregation to fall, this was announced

21 https://koranbanjar.net/guru-kapuh-ada-teladan-guru-sekumpul-menghadapisituasi-medis/, downloaded on Sunday 22 November 2020.

22 https://koranbanjar.net/kebijakan-isolasi-terkait-korona-guru-kapuh-serahkanpada-ahlinya/, downloaded on Sunday 22 November 2020.

${ }^{23}$ Fatwa Majelis Ulama Indonesia, No. 14 Tahun 2020, Penyelenggaraan Ibadah Dalam Situasi Terjadi Wabah Covid-19, https://mui.or.id/berita/27674/fatwa-penyelenggaraanibadah-dalam-situasi-terjadi-wabah-covid-19/, downloaded on Sunday, 22 November 2020.

24 https://apahabar.com/2020/03/guru-kapuh-imbau-pesantren-dan-majelis-taklimdi-hss-libur/, downloaded on Sunday 22 November 2020. 
in digital media on April 9, 202025. He said that the law of fardhu' ain is implemented if there is no udzur or obstruction in accordance with the rules. Meanwhile, with the Covid-19 pandemic, which is spreading rapidly, the local government has recommended limiting the distance between residents. This policy is aimed at minimizing the spread and breaking the cycle of the spread of Covid-19. These conditions and policies are the $u d z u r$ for Muslims to abort the fardhu 'ain law on Friday prayers and eliminate the fardhu prayers in congregation in mosques or other places of worship. He also said that to compare the issue of the failure of Friday prayer obligations with the closing of the market, these two things cannot be compared because they have nothing to do, and the issue of market closure is beyond the authority of the ulama.

The HSS Regency Government and the HSS Regency MUI agreed on November $11^{\text {th }}, 2020$ to allow Muslims in the HSS Regency to return to perform Friday Prayers and prayer 5 times in congregation at the mosque. ${ }^{26}$ In this agreement, people who have heart disease, kidney failure, high blood pressure, diabetes, high blood pressure, and asthma were urged to pray at home only. On Friday, $13^{\text {th }}$ November 2020, it was the first Friday after allowing the implementation of Friday prayers in the HSS Regency. The HSS Regent held Friday prayers in congregation at the Al-Hidayah Kapuh Mosque with the head of the HSS Regency MUI. ${ }^{27}$ The implementation of Friday prayers still following health protocol with the provision of wearing masks, washing hands, and maintaining a minimum distance of one meter between congregations.

Guru Kapuh as a popular religious figure in the HSS Regency also gave an appeal about the holding of regional head elections during the Covid-19 period. He appealed to the public to create a conducive atmosphere when facing regional head elections and Covid-19. The public was advised to avoid money politics and not to spread hate speech or news that is not in accordance with the facts or hoax ${ }^{28}$. The public must also pay attention to health protocols in holding regional head elections. Guru Kapuh's appeal in this context invited the public to prioritize physical health by paying attention to health and mental health protocols by avoiding negative actions in regional head elections.

KH. Ahmad Zuhdiannoor, commonly known as Guru Zuhdi, is a charismatic ulama in South Kalimantan and domiciled in the city of Banjarmasin. Guru Zuhdi is a student of Guru Sekumpul, the same as Guru

25 https://kalsel.antaranews.com/berita/159054/guru-kapuh-ijtihad-ulamakewajiban-shalat-jumat-gugur-karena-cegah-wabah-corona, downloaded on Sunday 22 November 2020.

26 https://www.teras7.com/pemerintahan/akhirnya-pemerintah-dan-mui-hsssepakat-perbolehkan-salat-jumat/, downloaded on Sunday 22 November 2020.

27 https://infobanua.co.id/2020/11/14/tangkal-covid-19-warga-hss-sudah-bolehsalat-berjamaah-di-mesjid/, downloaded on Sunday 22 November 2020.

28 https://kalselpos.com/2020/11/03/guru-kapuh-ajak-kaum-muslimin-ciptakanpilkada-damai-dan-kondusif-\%E2\%80\%8E/, downloaded on Sunday 22 November 2020. 
Kapuh. Not many fatwas from Guru Zuhdi have been found, because he died on Saturday, May 2, 2020 at Medistra Hospital, Jakarta ${ }^{29}$. Before issuing a fatwa regarding social restrictions, Guru Zuhdi had led a joint prayer at the Sabilal Muhtadin Mosque to be given safety and patience in facing the Covid19 pandemic $^{30}$. He gave a strengthening of confidence to the community to keep thinking positively about what people were experiencing. His statement in increasing the community's faith was "God must do something, including Corona, but we don't know". This statement affirmed that all the destinies and decrees that have occurred must have a wisdom behind them, because something will not happen but with His will.

Guru Zuhdi expressed his readiness to follow and to assist the government in conveying policies related to social restrictions and the implementation of health protocols. ${ }^{31}$ In realizing his support for the government, he dismissed all the recitations under his guidance ${ }^{32}$ and appealed to the public to remain at home 33 . Only a few fatwas or decrees related to Covid-19 were found. In addition, another ulama, KH. Himran Mahmud, as the head of the Darul Ilmi Banjarbaru Islamic Boarding School ensured that all activities or activities that have the potential to accumulate mass will be stopped. ${ }^{34}$ This indicated that scholars in big cities also supported government programs during the Covid-19 period.

\section{Forms of Ulama Leadership}

A leadership is the interaction of more than one person involving the leader, followers, and the organization ${ }^{35}$. A leader is certainly formed by individuals who are under him/her, which indicates that leaders cannot rule themselves without subordinates (people or congregation). Leadership is formed ideally when in an association (organization, bureaucracy, state, etc.). The definition of leadership in general that has been previously disclosed clearly states that leadership has several elements; leaders, followers, organization, and circumstances. A leader is an elected person who is trusted by a group to make changes through the policies he/she implements. Followers are groups of individuals who choose a leader and fill an organization. An organization is

\footnotetext{
${ }^{29}$ https://republika.co.id/berita/q9pnhb320/wafatnya-guru-zuhdi-kehilangan-besarbagi-umat-islam-kalsel, downloaded on Sunday 22 November 2020.

30 https://apahabar.com/2020/03/guru-zuhdi-doakan-virus-corona-segera-lenyap/, downloaded on Sunday 22 November 2020.

31 https://dutatv.com/pernyataan-lengkap-para-tokoh-kalsel-menanggapipenyebaran-corona/, downloaded on Sunday 22 November 2020.

32 https://kanalkalimantan.com/antisipasi-corona-guru-zuhdi-liburkan-semuapengajian-berikut-jadwal-rutinnya/, downloaded on Sunday 22 November 2020

33 https://wartatanbu.co.id/pengajian-libur-sementara-guru-zuhdi-mintamasyarakat-berdiam-diri-di-rumah/, downloaded on Sunday 22 November 2020.

34 https://republika.co.id/berita/q7o7jh366/ulama-kalsel-minta-umat-ikuti-anjuranpemerintah-soal-corona, downloaded on Sunday 22 November 2020.

35 Justin A. Ramirez, Public leadership, New York: Nova Science Publishers, 2011, p. 121.
} 
a collection of several individuals who have the same thoughts and common goals.

A leadership has three styles or models consisting of laissez-faire leadership, transformational leadership and transactional leadership. ${ }^{36}$ Laissez-faire leadership is the leadership that avoids its role as a leader, the context of avoidance in this definition is avoiding situations where the community or congregation needs a leader to direct them. ${ }^{37}$ Leaders in laissesz-faire leadership syle only give employees a broad set of goals or multiple tasks without showing details about how they were accomplished or measured carefully. ${ }^{38}$

Transformational leadership has four dimensions of a leader who standardizes leadership; having an ideal influence (acting as a public figure through behavior), providing inspirational motivation (a collection of interesting and inspiring visions about the future), generating intellectual stimulation (challenging existing assumptions and stimulating new ways of thinking), and individual consideration (paying attention to the needs and concerns of society) ${ }^{39}$. Transformative leaders motivate and encourage their community or congregation to take risks and achieve their own success, take advantage of a creative environment, and stimulate people to behave innovatively. ${ }^{40}$ Transformational leadership describes how a leader tries to meet the needs that is most needed by society ${ }^{41}$.

Leaders with a transactional leadership style give rewards when their subordinates do what is expected and provide punishment if they do not behave as expected ${ }^{42}$. This type of leadership is static because it already has provisions in its performance; if subordinates do what the leader wants, they will get a reward or prize. On the other hand, if they do not do what the

36 Habtamu Kebu Gemeda, Jaesik Lee, Leadership styles, work engagement and outcomes among information and communications technology professionals: A CrossNationl study, Heliyon, Vol. 6, 2020.

37 Kari Wik Agotnes, Anders Skogstad, Jorn hetland, Olav Kjellevold Olsen, Roar Espevik, Arnold B. Baker, Stale Valvatne Eirnasen, Daily Work Pressure and Exposure to Bullying-related Negative Acts: The Role of Daily Transformational and Laissez-faire Leadership, European Management Journal, 2020.

38 Alexander Fries, Nadine Kammerlander, Max eitterstorf, Leadership Styles and Leadership Behaviors in Family Firms: A Systematic Literature Review, Journal of Family Business Strategy, 2020.

39 Nathapon Siangchokyoo, Ryan L. Klinger, Emily D. Campion, Follower Transformational As The Linchpin of Transformational Leadership Theory: A Systematic Review and Future Research Agenda, The Leadership Quarterly, Vol. 31, No. 1, 2020.

40 Mohsin Shafi, Zoya, Zheng lei, Xiaoting Song, Md Nazirul Islam Sarker, The Effects of Transformational Leadership on Employee Creativity: Motivating Role of Intrinsic Motivation, Asia Pasific Management Review, Vol. 25, No. 3, 2020.

41 George C. Banks, Kelly Davis McCauley, William L. Gardner, Courtney E. Guler, A Meta-Analytic Review of Authentic and Transformational Leadership: A Test for Redundancy, The Leadership Quarterly, Vol. 27, No. 4, 2016.

42 Olga Epitropaki, Robin Martin, Transformational-Transactional Leadership and Upward Influence: The Role of Relative Leader-Member Exchange (RLMX) and Perceived Organizational Support (POS), The Leadership Quarterly, Vol. 24, No. 2, 2013. 
leader wants, they will get punishment. However, the advantages of this leadership are providing clarification of the subordinates expectations, to set the organizational goals more important than any other goals, providing an explanation of how to achieve what is expected, clearly informing the criteria of the performance to be evaluated, generating feedback to individuals or groups who meet the achievement, and prepare rewards and punishments for the end of the activity result 43 .

Three religious figures who became the spotlight in this study are Guru Zuhdi, Guru Kapuh, and KH. Himran Mahmud. From these three ulama, the most revealed data was from Guru Kapuh because he was the head of the MUI HSS Regency. From the results of data collection through internet, Guru Kapuh issued several decisions in support of government policy programs on Covid-19. These forms of support are by giving statements through the media that Guru Kapuh supports the government to prioritize common health and safety factors, appeal to all non-formal Islamic education institutions to be closed until the specified time limit, issue a fatwa regarding the failure of the law of fardhu 'ain on Friday praying, advocating for congregational prayers at the mosque to be replaced with prayers at home, and calling on the public to eliminate religious activities such as dhikr assemblies; recitation; takbir akbar; and other religious activities that have the potential to gather the mass. Besides the fatwa on religious worship, Guru Kapuh also gave an appeal to regional politics. He appealed to the public who participated in regional head elections not to do negative things such as money politics and spread hoax and also to keep prioritizing health protocols.

Guru Zuhdi as the ulama who has the most congregations in the city of Banjarmasin, announced that the recitation under his supervision would be closed and appealed to the people of Banjarmasin to stay at home, given the density of the urban population. In addition, KH. Himran Mahmud emphasized that all activities that had the potential to gather mass would be stopped, including closing the Islamic boarding school he led. Ulama leadership in community life has three categories. They are traditional, charismatic and rational. It is traditional if the community obeys the ulama because of their mastery of religious literacy, charismatic if the community obeys the ulama because of the charisma that appears, and rational if the community obeys the ulama because of the logical and contextual orientation. ${ }^{44}$

These three ulamas act as a liaison between the government and society, as well as reinforcing the policies implemented by the government. Their position as clerics who become role models for the wider community

43 Lutfi Adin Affandi, Mohammad Rizan, Kepemimpinan Transformasional, Transaksional, Motivasi Kerja, dan Kinerja Personil Satuan Provost Detasemen Markas Mabes Angkatan Laut, Jurnal Pendidikan Ekonomi dan Bisnis, Vol. 3, No. 2, 2015.

${ }^{44}$ Zaenal Arifin, Kepemimpinan Kiai dalam Ideologi Pemikiran Santri di PesantrenPesantren Salafiyah Mlangi Yogyakarta, Inferensi: Jurnal Penelitian Sosial Keagamaan, Vol. 9, No. 2, 2015 
has an influence on what is said and acted. When the closure of the recitation and the closing of the Islamic boarding school were announced, none of the people protested against their appeal. Likewise, when issuing a fatwa on the abrogation of the fardhu 'ain law on Friday prayers, it did not cause controversy in the entire community, even though there were people who continued to perform Friday prayers.

The behaviors modeled by these ulamas have accommodate what the government wants and society needs. With the difficulty of mobility during this pandemic, the ulama continued to carry out spiritual guidance by holding recitations online. Thus, the spiritual needs of the community are still fulfilled. It is through this online recitation that ulamas keep reminding the public to follow government recommendations. The act of holding online recitation is a form of the ulama's concern for the community. In other words, the ulamas remain a figure who are capable of leading the community in any condition and minimizing conflicts against government policies that have the potential to conflict with religion, such as regarding Friday prayers. This kind of leadership includes transformational leadership because the ulamas care and have concerned on society and become mediators between society and the government. Ulamas have become influential figures in South Kalimantan to convey the policies created by the government during the Covid-19 pandemic. ${ }^{45}$ This fatwa from the Ulama has become a concrete role as a moderator between citizens and the government. ${ }^{46}$

\section{Closing}

This study raises data showing that the ulamas in South Kalimantan practice the transformational leadership in religious life. In this case, the government as the manager of an area needs a religious leader who has a good image and popularity in society. Besides the Regional Head who leads an area, it is also necessary to have an Ulama who leads the spirituality of the community in an area, so that the community spiritual needs can be met. In other words, the ulama remains a community figure who is the most important figure for any condition and can minimize any conflicts to happen among society and government.

45 https://www.antaranews.com/berita/1377014/ulama-serukan-masyarakat-ikutikebijakan-pemerintah-cegah-corona, downloaded Thursday 19 November 2020.

46 Saiful Mujani, Deni Irvani, Sikap dan Perilaku Warga Terhadap Kebijakan Penanganan Wabah Covid-19, Politika, Vol. 11, No. 2, 2020. 


\section{Bibliography}

Affandi, Lutfi Adin, Mohammad Rizan, Kepemimpinan Transformasional, Transaksional, Motivasi Kerja, dan Kinerja Personil Satuan Provost Detasemen Markas Mabes Angkatan Laut, Jurnal Pendidikan Ekonomi dan Bisnis, Vol. 3, no. 2, 2015.

Agotnes, Kari Wik, Anders Skogstad, Jorn hetland, Olav Kjellevold Olsen, Roar Espevik, Arnold B. Baker, Stale Valvatne Eirnasen, Daily Work Pressure and Exposure to Bullying-related Negative Acts: The Role of Daily Transformational and Laissez-faire Leadership, European Management Journal, available online, 2020.

Amrullah, M, Kholis, M. Irfan Islamy, Perencanaan Penelitian, Malang : Literasi Nusantara, 2020.

Arifin, Zaenal, Kepemimpinan Kiai dalam Ideologi Pemikiran Santri di Pesantren-Pesantren Salafiyah Mlangi Yogyakarta, Inferensi: Jurnal Penelitian Sosial Keagamaan, Vol. 9, No. 2, 2015.

Aswasulasikin, Siti Irene Astuti Dwiningrum, Sumarno, Tuan Guru sebagai Tokoh Pembangunan Pendidikan di Pedesaan, Pembangunan Pendidikan: Fondasi dan Aplikasi, Vol. 3, No. 1, 2015.

Bahtiar, Edi, Aktualisasi Peran Ulama Sebagai Warasatul Anbiya dalam Konteks Kehidupan Beragama dan Bernegara, Riwayah, Vol. 4, No. 1, 2018.

Banks, George C., Kelly Davis McCauley, William L. Gardner, Courtney E. Guler, A Meta-Analytic Review of Authentic and Transformational Leadership: A Test for Redundancy, The Leadership Quarterly, Vol. 27, No. 4, 2016.

Epitropaki, Olga, Robin Martin, Transformational-Transactional Leadership and Upward Influence: The Role of Relative Leader-Member Exchange (RLMX) and Perceived Organizational Support (POS), The Leadership Quarterly, Vol. 24, No. 2, 2013.

Faris, Nezar, Mohamad Abdalla, Leadership in Islam Thoughts, Processes and Solutions in Australian Organizations, Switzerland: Springer, 2018.

Fatwa Majelis Ulama Indonesia, No. 14 Tahun 2020, Penyelenggaraan Ibadah Dalam Situasi Terjadi Wabah Covid-19, https://mui.or.id/berita/27674/fatwa-penyelenggaraan-ibadah-dalamsituasi-terjadi-wabah-covid-19/, diunduh pada Minggu 22 November 2020.

Fries, Alexander, Nadine Kammerlander, Max eitterstorf, Leadership Styles and Leadership Behaviors in Family Firms: A Systematic Literature Review, Journal of Family Business Strategy, 2020.

Gemeda, Habtamu Kebu, Jaesik Lee, Leadership styles, work engagement and outcomes among information and communications technology professionals: A Cross-Nationl study, Heliyon, Vol. 6, 2020.

Gibson, William, Andrew Brown, Working With Qualitative Data, California: SAGE Publications, Inc, 2009. 
Guglielmo, Frank, Sudhanshu Palsule, The Social Leader: Redefining Leadership for Complex Social Age, Brookline: Bibliomotion, 2014.

Haries, Akhmad, Hervina, Pandangan Ulama tentang Hukum Surung Sintak pada Pelaksanaan Zakat Fitrah di Kota Samarinda, Fenomena, Vol. 5, No. 2, 2013.

Https://Apahabar.Com/2020/03/Guru-Kapuh-Imbau-Pesantren-DanMajelis-Taklim-Di-Hss-Libur/, diunduh pada Minggu 22 November 2020.

Https://Apahabar.Com/2020/03/Guru-Zuhdi-Doakan-Virus-Corona-SegeraLenyap/, diunduh pada Minggu 22 November 2020.

Https://Dutatv.Com/Pernyataan-Lengkap-Para-Tokoh-Kalsel-MenanggapiPenyebaran-Corona/, diunduh pada Minggu 22 November 2020.

Https://Infobanua.Co.Id/2020/11/14/Tangkal-Covid-19-Warga-Hss-SudahBoleh-Salat-Berjamaah-Di-Mesjid/, diunduh pada Minggu 22 November 2020.

Https://kalsel.antaranews.com/berita/154558/video-cegah-corona-gurukapuh-liburkan-ponpes, diunduh kamis 19 November 2020.

Https://Kalsel.Antaranews.Com/Berita/159054/Guru-Kapuh-Ijtihad-UlamaKewajiban-Shalat-Jumat-Gugur-Karena-Cegah-Wabah-Corona, diunduh kamis 19 November 2020.

Https://Kalsel.Antaranews.Com/Berita/159054/Guru-Kapuh-Ijtihad-UlamaKewajiban-Shalat-Jumat-Gugur-Karena-Cegah-Wabah-Corona, diunduh pada Minggu 22 November 2020.

Https://Kalselpos.Com/2020/11/03/Guru-Kapuh-Ajak-Kaum-MusliminCiptakan-Pilkada-Damai-Dan-Kondusif-\%E2\%80\%8e/, diunduh pada Minggu 22 November 2020.

Https://Kanalkalimantan.Com/5-Bulan-Semenjak-Kasus-Pertama-Covid-19Di-Kalsel-Nyaris-Tembus-9-Ribu-Kasus/, diunduh pada Minggu 22 November 2020.

Https://Kanalkalimantan.Com/Antisipasi-Corona-Guru-Zuhdi-LiburkanSemua-Pengajian-Berikut-Jadwal-Rutinnya/, diunduh Kamis 19 November 2020.

Https://Kanalkalimantan.Com/Antisipasi-Corona-Guru-Zuhdi-LiburkanSemua-Pengajian-Berikut-Jadwal-Rutinnya/, diunduh pada Minggu 22 November 2020.

Https://Kanalkalimantan.Com/Breaking-News-1-Orang-Positif-Covid-19-DiKalsel-Kasus-Pertama-Ditemukan/, diunduh pada Minggu 22 November 2020.

Https://Koranbanjar.Net/Guru-Kapuh-Ada-Teladan-Guru-SekumpulMenghadapi-Situasi-Medis/, diunduh pada Minggu 22 November 2020.

Https://Koranbanjar.Net/Kebijakan-Isolasi-Terkait-Korona-Guru-KapuhSerahkan-Pada-Ahlinya/, diunduh pada Minggu 22 November 2020. Https://Republika.Co.Id/Berita/Q7o7jh366/Ulama-Kalsel-Minta-Umat-IkutiAnjuran-Pemerintah-Soal-Corona, diunduh pada Minggu 22 November 2020. 
Https://Republika.Co.Id/Berita/Q9pnhb320/Wafatnya-Guru-ZuhdiKehilangan-Besar-Bagi-Umat-Islam-Kalsel, diunduh pada Minggu 22 November 2020.

Https://Wartatanbu.Co.Id/Pengajian-Libur-Sementara-Guru-Zuhdi-MintaMasyarakat-Berdiam-Diri-Di-Rumah/, diunduh pada Minggu 22 November 2020.

Https://www.antaranews.com/berita/1377014/ulama-serukanmasyarakat-ikuti-kebijakan-pemerintah-cegah-corona, diunduh Kamis 19 November 2020.

Https://Www.Teras7.Com/Pemerintahan/Akhirnya-Pemerintah-Dan-MuiHss-Sepakat-Perbolehkan-Salat-Jumat/, diunduh pada Minggu 22 November 2020.

Khiyarusoleh, Ujang, Konseling Indigenous Pesantren (Gaya Kepimpinan Kyai dalam Mendidik Santri), Jurnal Kependidikan, Vol. 6, No. 3, 2020.

Longhofer, Jeffrey. Et. All., Qualitative Methods for Practice Research, Oxford: Oxford University Press, 2013.

Mujani, Saiful, Deni Irvani, Sikap dan Perilaku Warga Terhadap Kebijakan Penanganan Wabah Covid-19, Politika, Vol. 11, No. 2, 2020.

Nuar, Jannatul Husna bin Ali, Minangkabau Clergies and The Writing of Hadith, Ushuluddin, Vol. 24, No. 1, 2016.

Nugroho, Arifin Suryo, Visi Politik Seorang Ulama, Khazanah Pendidikan, Vol. 13, No. 2, 2020.

Ramirez, Justin A., Public leadership, New York: Nova Science Publishers, 2011.

Ratodi, Muhamad, Arfiani Syariah, Perubahan Spasial Wilayah Permukiman Muslim Sekumpul Terkait Aktivitas Dakwah KH Muhammad Zaini Abdul Ghani, Emara: Indonesian Journal of Architecture, Vol. 5, No. 2, 2019.

Ruslan, Luthfiyah, Pendampingan Ustadz dan Tuan Guru Pesantren melalui Pneguatan Nilai-nilai Multikultural untuk Mencegah Radikalisme Islam Berbasis Pesantren di Kota Bima, Engagement, Vol. 4, No. 1, 2020.

Saldana, Johnny, Matt Omasta, Qualitative Research: Analyzing Life, California: SAGE Publications, Inc, 2018.

Shafi, Mohsin, Zoya, Zheng lei, Xiaoting Song, Md Nazirul Islam Sarker, The Effects of Transformational Leadership on Employee Creativity: Motivating Role of Intrinsic Motivation, Asia Pasific Management Review, Vol. 25, No. 3, 2020.

Siangchokyoo, Nathapon, Ryan L. Klinger, Emily D. Campion, Follower Transformational As The Linchpin of Transformational Leadership Theory: A Systematic Review and Future Research Agenda, The Leadership Quarterly, Vol. 31, No. 1, 2020.

Suradi, Ahmad Adi, Buyung Surahman, Kiai's Role as Ulama and Umara: Implications to The Pesantren Education, Masyarakat, Kebudayaan, dan Politik, Vol. 33, No. 2, 2020. 
The South Kalimantan Ulama's Leadership in Covid-19 Pandemic Era 